\title{
The Baul Sursadhak: The Tradition and Individual Talent
}

\author{
Jayita Sengupta \\ Sikkim University, Gangtok, India
}

\begin{abstract}
The Bauls or the fakirs of Bengal have been unacknowledged prophets even a century back, till the recent interest now in their music, philosophy, and performance. The Bauls do not revere class/caste/religious divides and often flout the norms of the society by their divine madness. Etymologically, the word derives from Sanskrit, "vatula" (meaning one who is affected by the wind disease or is mad), or "vyakula” (meaning restless or disordered). In recent years however, Bauls have been recognized as a religious sect, yet the connotation of madness still clings to their reputation. This paper is going to discuss briefly how the Baul tradition developed in Bengal and then focus on the Baul philosophy in the Baul-gan texts and on their musical appeal. Many of the Baul-gans have had profound influence on other forms of music. Closely associated with the Baul sangeet is the Bhatiali music whose rhythm, has often won the hearts of many classical musicians. Often times the classical musicians have been found to render the ektatra or dotara sounds in their improvisations. Rabindranath Tagore too has used some of the Baul maestro, Lalon Fakir's lyrics, philosophy as well as music in many of his songs. More recently, Baul songs have been rendered through fusion bands or experimental music.
\end{abstract}

Keywords: baul, fakir, music, philosophy, performance, tradition

\section{Introduction}

How does one define a sursadhak? Why should we associate this term with Baul sangeet? Are the Bauls and the Fakirs, part of the same group? What are the influences of this specialized group of musician-philosophers on other forms of music and literature? Possibly these are some of the issues which my paper intends to address and discuss here.

As Sudhir Chakraborty (Kolkata, 2010, pp. 171-2), the well known scholar on Baul philosophy and music, tells us, the baul and fakir are often used together as a hyphenated word. Yet, are the two groups essentially the same? Bauls have won favour among the common people, research scholars, and lovers of music. But the fakirs? Did they elicit the same kind of response from the masses? Chakraborty points out that the bauls and fakirs have different haunts at the Poushmela in Santiniketan. However, the bauls and fakirs in Nadia-Murshidabad districts have come together as Baul-Fakir Sangha to resist the oppression and ill treatment by the Muslim fanatics or "moulavis". Otherwise, fakirs have often been relegated to the margin. Only recently in the last few years, the Gorbhanga Fakiri Utsav in Nadia which includes the bauls, have gained popularity in the state of West Bengal. Fakirs are Muslims, whereas Bauls Hindus, yet they are neither Hindu nor Muslim. Bauls and fakirs both do not revere class/caste/religious divides and often flout the norms of the society by their divine madness. Their refusal to accept the fundamental bases of social organization stems from their insistence to judge men with love and not necessarily as a member of a group with pre-ordained virtues or faults. The 
orthodox Muslims hate the fakirs as the latter is aberrant in observing the rituals of their religion. They like the bauls who reject the dry or "sukhno" doctrinal path to salvation and opt for the "rasik" or "juicy" one. The word "rasik" rather hard to translate derives from "rasa" which basically means "sap"; all its connotative meanings have reference to a kind of freshness and vitality, both physical and mental. The bauls and fakirs find "celibacy" enjoined upon ascetics as repugnant and ridiculous. According to them, sexual intercourse is a sine qua non for the preservation and increase of such virtue. Such a belief and its ritualistic expression is a secret matter among the baul-fakirs and often forms the text of their songs. The song by Lalon Fakir which beautifully illustrates the philosophy of a baul-fakir life is:

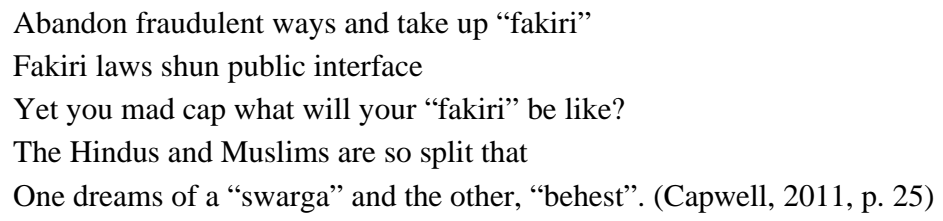

The true fakir does not dream of a "heaven”. He wants only his "Allah" and he craves for him just as a lover would for his beloved. For the bauls too Chaitanya's frenzied adoration for Krishna is their ideal of craving for the divine.

Etymologically, the word "baul" derives from Sanskrit, "vatula" (meaning one who is affected by the wind disease or is mad), or "vyakula" (meaning restless or disordered). If a baul is "vyakul" for the vision of Gobinda, the fakir is "diyana” for his "Allah". While there are fixed hours for "arati' and azaan, a baul or a fakir would disagree. Beloved God surely does not abide by specific hours for prayers and conversations. He is always with you, so all these extravaganzas would better be done away with. Similarly, a mandir or masjid is not constructed of minaret and stone but is of one's own heart. A baul or fakir would construct a mandir or masjid of devotion in his heart where God always resides and is one's own. Charles Capwell in his book, Sailing on The Sea of Love (Kolkata, 2011), refers to the bauls as a religious sect. But in my opinion and as others might agree, the bauls and fakirs are not religious sects in the conventional sense of the term. They are "sadhaks", or mendicants irrespective of any religious/caste/class barriers. The fakirs have a tougher time than the bauls, with the Muslim fundamentalists. Bauls as a derivative of the Bhakti movement have acquired acceptance in society, but the fakirs do not find a ready acceptance in the Muslim culture. Possibly the origin of the Fakiri cult goes back to Sufism.

The sufis were the first to protest against the ritualistic ways of doctrinal religion. To them a Haj or Roja or Azaan was insignificant. Instead of abiding by the laws of the religion, they would rather obey the directives of their souls devotion. The word, "sufi" owes its origin to Arabic "suf" which means wool. When these sufis had first come to India, they wore gowns made of "suf”. Later as they stayed on, they did not need such warm clothing and the "suf" gowns were replaced by cotton allkallahs. As Ranjan Bandyopadhyay tells us, (Kolkata, 2011, p. 180) in the early years of Islamic history, people led a very simple and idealistic life. Even the second Khalifa wore a "suf" garment. However, soon after, luxurious lifestyle became a part of Islamic culture. But a group of people protested against the new lifestyle and they were identified as one who wore suf gowns and thus were named as sufis. According to historical analysis however, it would be erroneous to refer to the sufi movement as a protest movement. The sufis with their ideal of simple, non-materialistic ways of life were concurrent with the development of the Islamic culture and society. In its essence, Sufism is Islamic, as "Islam" in Arabic means peace and submission at the altar of the divine or to the faith that Allah is almighty. Those who 
submit to this faith are the followers of Islam. However, as the religion would have it, the follower of Islam has to abide by some laws of this faith or "akida", which include kalma, roja, jakat, and haj. A fakir denounces these five "akidas", and goes as far as to make fun of them.

A five times namaz

Who can stop him from obtaining shariyat? (Lalon Fakir)

So the fakirs in the eyes of the orthodox Muslims are "besras". The fakirs too believe in Gurus or "Murshids", and often to them Guru and God are one, which comes close to the Guru mantra in the Upanishads.

Guru Bramha, Guru Vishnu, Gurudeva Maheshwara,

Guru sakshat param Bramha

Tasmoi shri Guruve namaha

In a different vein, the famous sufi song by Amir Khusrao, “Cchap tilak sab cchini re mose naina milaike”, speaks of the disciple's unqualified devotion for his Guru, Hazrat Nizamuddin Aulia. Unlike the solemnity in the dhrupadi style of the Upanishadic hym quoted above, the song revels in projecting the Guru, as a "cloth dyer", or one who dallies in colours of life, as the lover whose glance has the love potion to feminize Khusrao, and compel a complete submission from him. No thoughts of status, title, name, and fame could deter him from responding to his Guru's love for him, as their eyes meet, he abjectly submits to his gaze, and becomes his "bride”. The gendering phenomenon in the disciple "becoming” his Guru's "bride”, may appear queer, yet, such is also Sri Chaitanya's love for Krishna, or Arjuna’s devotion for Parthasarathi.

However, the idea of a Guru or Murshid and that being synonymous with Allah, surely is heretical and there is enough reason for the maulavis to call the fakirs non-Islamic and "mushrik" or "Bedouin" meaning "the faithless". Essentially devotional, the fakir ascetics like the Bauls follow the path of meditation. However within the two groups also there are many sub groups or "gosthis", each adopting secret ways of meditative practices, for divine apprehension. Only one, who is initiated into that particular subgroup and accepts the head or "goshai" as their Guru, has access to that secret knowledge and codes. Quite often however these secretive methods of meditation or "kriyas", are the texts of the songs, which have the power to baffle the ordinary listener. Often, the message has to be decoded through proper understanding of the Baul-fakir philosophy, or what is called the "dehotattvo" (body), "prematattvo" (spiritual love), "gurutattvo" (spiritual preceptor), "lilatattvo" (dalliance of Radha and Krishna), "guhyotattvo" (esoteric), "bhajantattvo” (worship), "parotattvo” (transcendental), "bhaktitattvo” (devotion), and “monosiksha” (self-realization).

According to "Dehotattva”, enjoyment of full desire eventually leads to pure love in a baul's sadhana. The baul then perceives the full lila or the divine play of Radha and Krishna. Jogendra Nath Bhattacharya relates the concept of the "dehotattvo" to the ingestion of human excretions, which are called "Four Moons" (Bhattacharya, 1896, p. 381) While the secrets remain unknown to an outsider, Capwell points out that the practice finds mention in one of the old tantric treatises, titled, Hevarja. In the treatise, the "four moons" or the excretions: Urine, faeces, semen, menses are mentioned as camphor, musk, frackincense, and a potion of four ingradients, which together are defined as sanghabhasa (coded language in Sanskrit). Banerjee, in Siva Samhita (Banerjee, 1894, p. 55), observes that there is a lengthy tradition behind matters connected with the sexual rite. A coitus reservation is performed during the ritual, where it is necessary for the male to gain control over sphincter muscles in order to prevent ejaculation and ejection of urine with the help of "vayu" or yogic breath control to 
attain the Bindu Siddhi or semen control. A song which had attracted young Lalon and which made him recognize his Guru is one of "Dehotattvo": "manob deho motor gari, chalao sadhan... ” A translation of the song by Capwell is as follows:

Drive the human-body-motor-car upon the road of sadhona

Be informed of who is your mind-driver

By the word of a true guru.

Two lights are at the front of the car;

They are lit day and night; they don't go out.

A car with seven locks; keep alert, $\mathrm{O}$ mind, while driving.

Within the car are two conductors; there are also sixteen acquitted men within.

Each is absorbed in his own work

And has no connection with anyone.

Hiramon says, "I remember the feet of the guru;

Come and drive for me now.

“I cannot drive your car any longer in your material kingdom”. (Capwell, 2011, p. 199)

The "seven locks" here are the seven yogic plexuses, or chakras, the "two conductors", the two yogic nerves, Ida and pingala. A cosmic chant by Paramahansha Yogananda, harps on the same theme differently and could be an interesting case for intertextual study if the songs are compared.

\author{
Why $\mathrm{O}$ mind wanderest thou? \\ Go in thy inner home! \\ On the left, Ida; on the right, Pingala; \\ In the middle, taintless Sushumna. \\ Seize , seize Her with all thy might! \\ Kundalini power in the subtle form \\ Liveth unconscious in the coccyx region \\ Guru-given power, by pranayama wake, \\ Wake Her with all thy might! (Yogananda, 1982, p. 62)
}

If the baul-fakir would use ritualistic tantras for self-realization, the kriya yoga taught by Paramahansa Yogananda is pranayama based, where the control of breath would help in controlling the chakras, and stimulate the sexual or kundalini energy, driving it upwards through the spine to the cerebral region for attaining a "Samadhi", or sublimation with the cosmic perception. The ultimate aim for both the tattvas is self control, so that the dwelling place of the soul is not abused. If the kriya yoga would preach conservation of energy, the baul philosophy revels in a spiritual-carnal ethics of desire for a desireless desire. So there's always an element of the sringar rasa in the baul songs and the idea of transcending the same. Yet, a baul will never disclose his philosophy so simplistically. Beneath the veneer of the rustic, sometimes bordering on the crude sexual puns, there is the subtlety to be unravelled to fathom the meaning. While a baul song revels in riddles (heyalis) and is sometimes overt in the use of sexual puns, the chant quoted earlier is direct and refined of the rustic colour. Yet, the ultimate desire expressed in all the baul songs is that of God and self realization. However, there are certain songs like the one: "Chander gaye chand legecche, amra bhebe korbo ki/jhiyer pete mayer janmo tare tomra bolo ki etc" which are so riddled with esoteric meanings and ritualistic connotations 
that they absolutely take the listener by surprise and a culture shock sometimes.

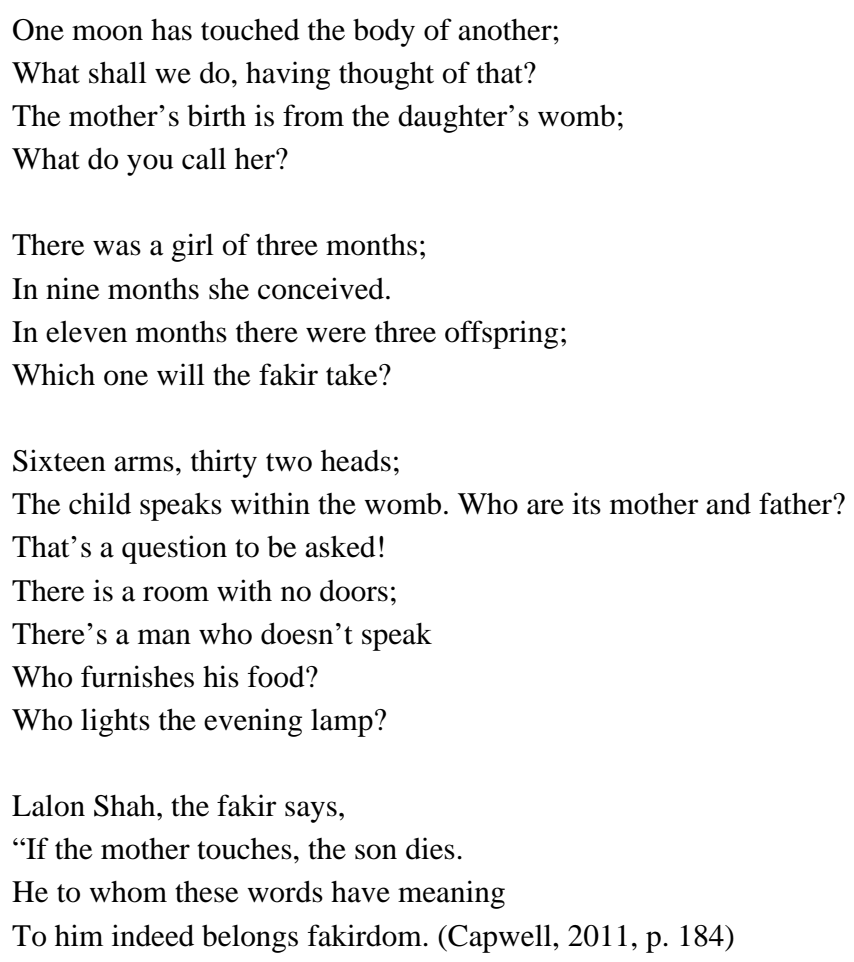

The first two lines here talk about the mystery of conception, the second and third are involved puns, where "jhi" could mean daughter or maidservant, and again "Ma", could be the affectionate way of addressing small girls. The confusion created here is a deliberate one. As Capwell rightly analyzes, the three months referrred to in the song are the three residences of man, namely the "father's head" which contains the desire for a sexual union with the mother, the mother's womb and finally the material world after birth. While it takes three months for the distillation of semen in the father's head, nine in addition to three together makes it twelve, when a girl attains her puberty. The term of pregnancy is generally ten months and ten days. Three offspring referred to here are the three attributes that one is born with namely, gyan (consciouness), buddhi (intellect), bal (physical capacity), along with ksudha (hunger), sabdo (vocal sound), and bhay (fear). These could correspond to the three deities, namely, Vishnu, Maheshwara, and Bramha. Of these deities, Vishnu is the fakir, because he is also a "sadhak" or the ascetic devotee. The sixteen arms referred to in the song, are the five sense organs and five physical organs, such as speech, hands, feet, anus, genitals, and six "ripu" or enemies, such as desire, anger, greed, infatuation, pride, and envy. The child, speaking in the mother's womb, is the Elusive Man, who has neither a mother nor father and is the Eternal Substance. Again this room, or house of the body could not be entered by any door to discover the individual personality, for Man as seed cannot speak. It is also a fact that many die as seed, at the touch of the mother. This knowledge surely is not easy to comprehend and one who does comprehend is a "fakir" and "sadhak". However, this balance between sexual-spiritual ethics is not easy to maintain, and Aksay Kumar Datto was extremely sceptical in his opinion of the bauls, for the emphasis they placed on carnal ethics. Yet, he was fully aware that "By enjoyment of desire they eventually come to experience pure love in their sadhana. Then they perceive the full lila (or divine play) of Radha and Krishna” (Datto, 1871, p. 168). Jogendranath Bhattacharya however, takes a more personal view of the bauls by 
suggesting that they were low class men, who by their costumes, musical instruments, dance and songs are characterized by a kind of queerness (Bhattacharya, 1896, p. 381). However, Bhattacharya too cannot do away with the fact that the aspect of the physical sadhana has its esoteric significances and has allegiance with the tantric Hevarja. The concept of the four moons in baul sadhana relates to the oldest tantrik treatise's mention of the human excretions in sandhabhasa or code language, as camphor, musk, frankincense and a potion of four ingredients. All these confirm that the tradition of sexual rites are ancient.

It was possibly the Tagore family which recast the image of the bauls freed from its tantric connections to that of Man as a humanist in search of the Supreme. As Tagore explained this very well:

These bauls have a philosophy which they call the philosophy of the body (kaya-sadhona); but they keep it a secret, it is only for the initiated. Evidently the underlying idea is that the individual's body is the Temple in whose inner mystic shrine the Divine appears before the soul, and the key to it has to be found from those who know... I had neither the training nor the opportunity to study this mendicent religious sect in Bengal from an ethnological stand point. (Tagore, 1922, p. 83)

In fact it is Tagore, who weds Sufism to the bauls in his philosophical treatise, The Religion of Man (1931). There is an artistic blend of the sufi-baul elements in his songs like "Bhenge mor Gharer cchabi" or "Kothay pabo tarey", which to a large extent retain the lyrics and the tune of Lalon Fakir's song. Tagore has adapted the baul philosophy in many of his writings too as in Phalguni, Prayascchitto, etc., where thought, music, and diction have blended into one in his creative imagination. His representation of the baul, as the poet-musician-prophet in such dramatical works is often speckled with perceptive wit and humorous wisdom, retaining thus the true tenor of the baul "ras" or aesthetics. The baul prophet is freed from the conventional necessities as he confronts life directly, without any social, religious, or personal ritual. Such refinement of the baul persona possibly has led to the expansion in Tagore's philosophical thoughts and ideas, and elevated the "baul”, from its lower class rustic stigma, but it has also led to the dilution of its complex philosophical content. More lately, the baul songs have been adapted into fusion bands, where it mingles with other related genres of music in Bengal.

In the context of the musical traditions practised in Bengal, the baul gaan is different from the bhaoyaiya and bhatiali, chiefly because of its rich philosophical content. There are however points where the three meet and there are points of departure. Quest for the ideal beloved, a longing for the Supreme in the heart of wilderness, are certain themes of the bhatiali songs. While bhaoyaiya would be based on the themes of love and separation, of Radha-Krishna's dalliance, bhatiali pertains to the songs of the boatman, on the srtetches of Ganga or Padma rivers. A song like "O bondhu re okuley bhasaiya...” haunts the listener with the pangs of separation, where the river itself becomes the metaphor of the divide between the lover and his beloved, who could be the Almighty. The idea of human isolation in the vast expanse of the unpredictable waters is manifested even more poignantly as the human is also the boatman steering his own self over the unchartered waters of life. The baul gaan is different in mood and tenor from these songs or palligeeti or folk songs, though certain elements of the other genres might have mixed with the baul instructive songs. There is a performative element with the baul gaan too, as it is always accompanied by dance and the playing of the ektara or dotara and sometimes a khonjoni. The baul performance is a one man show where the believer in baul ethics is also a musician who earns his bread through this profession. 


\section{Conclusion}

However, as everything in life is subject to change in the changing times, the essence of the baul spirit is gradually being lost in the wilderness of time. Many of the baul texts, of which only the initiated are aware of are lost, destroyed, or even if available are not easy to decipher. In the wake of globalization, the baul philosophy has lost its relevance and is being treated as just another love song with folk fusion elements only serving to entertain. The baul element remains at a very superficial level with the Bangla Bands, but the "sadhak", is dead.

\section{References}

Banerjee, B. N. (1894). Siva Samhita. Kolkata.

Bhattacharya, J. N. (1896). Hindu castes and sects. Calcutta: Firma.

Capwell, C. (2011). Sailing on the sea of love. Kolkata: Seagull.

Chakravorty, S. (2010). Baul Fakir Katha. Kolkata: Ananda Publishers.

Chakravorty, S. (2011). Gabhir Nirjan Pathey. Kolkata: Ananda Publishers.

Datto, A. K. (1871). Bharatbarshiyo Upasak Samproday. Calcutta: Karuna Prakashini.

Tagore, R. (1922). Creative unity. New York: Macmillan.

Yogananda, P. (1982). Cosmic chants. USA: Self Realization Fellowship Publication. 